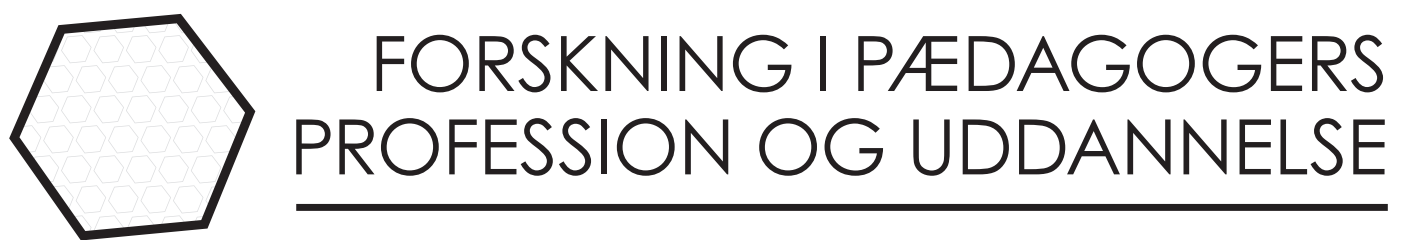

\title{
Implicit og eksplicit viden i tvarprofessionelt samarbejde
}

Om velfcerdsprofessionelles operationalisering af tidlig indsats og forebyggelse af udsathed gennem faglige vidensperspektiver

\section{Birgitte Theilmann \\ PhD, VIA University College bimt@via.dk}




\section{Resume}

Tidlig indsats og forebyggelse er blevet løsningen på velfærdsstatens problemer i relation til udsatte børn og unge. Kommunale forvaltninger ønsker at effektivisere og øge kvaliteten i indsatserne og kalder i den forbindelse på ny folles viden, der skal forandre organisationen. Her tilskrives teknologier, særligt organisationsopskrifter og det tværprofessionelle samarbejde, en særlig rolle. Artiklen sætter fokus på, hvordan fire grupper af fagprofessionelle medarbejdere (lærere, pædagoger, sundhedsplejersker og socialrådgivere) meningsudfylder nøglebegreberne tidlig indsats og forebyggelse af udsathed, ved at bringe forskellige vidensformer i spil, med henblik på at skabe en meningsfuld praksis. Artiklen peger på, at medarbejderne i høj grad trækker på mavefornemmelser, erfaringer og intuition (implicit viden) i løsning af den faglige opgave og i mindre grad på teknologier (eksplicit viden). Dette komplicerer vidensudvekslingen i det tværprofessionelle samarbejde. Teknologier anvendes i praksis enten når medarbejderne vurderer, at de passer ind i eksisterende faglig praksis, eller når de kan fungere som en legitimering af praksis (grundet ledelsesbeslutninger). Undersøgelsen peger således på, at organisationen er udfordret i forhold til den efterstræbte ny foelles viden.

\section{Abstract \\ Implicit and explicit knowledge on interdisciplinary cooperation - Operationalization of early intervention and prevention of vulnerability by means of professional perspectives}

Early intervention and prevention have become solutions to problems related to children and adolescents in vulnerable positions in the welfare state. Municipalities aim to increase the quality of the interventions and call for new common knowledge intending to change the organization. Technologies, especially organizational recipes, and interdisciplinary cooperation play important roles. The article highlights, how professional employees (teachers, day care workers, health care workers and social workers) make sense of the key concepts, early intervention and prevention of vulnerability by using different kinds of knowledge in order to create a meaningful practice. The article shows that professional employees to a large degree draw on feelings, experiences and intuition (implicit knowledge) when handling professional tasks, and to a lesser degree by using technologies (explicit knowledge). This complicates the knowledge exchange within interdisciplinary cooperation. Technologies are used either when the employees consider them suitable in existing practice or as a kind of legitimation of practice (due to managerial recommendations). The study shows the organization being overall challenged according to new, common knowledge.

\section{Nøgleord}

eksplicit viden, implicit viden, teknologier, organisationsopskrifter, tavs viden 
Key words

explicit knowledge, implicit knowledge, technologies, organizational recipes, tacit knowledge

\section{Introduktion}

Denne artikel undersøger, hvordan fire grupper af medarbejdere (lærere, pædagoger, socialrådgivere og sundhedsplejersker) gennem forskellige vidensformer (teknologier, professionsfaglig viden og erfaringer) operationaliserer en strategi om tidlig indsats og forebyggelse af udsathed i praksis igennem tværprofessionelt samarbejde. Artiklen bygger på en undersøgelse, som er en del af et større forskningsprojekt, hvor en gruppe forskere fra Aalborg Universitet i et samarbejde med Aalborg kommune, undersøger implementeringen af en udviklingsstrategi. Udviklingsstrategien (Udviklingsstrategi for børn, unge og familier i Aalborg Kommune 0-18/23 år, 2016) har til formål at reducere børn og unges udsathed. Dette er tiltænkt iværksat igennem tværprofessionelt samarbejde mellem de fire faggrupper og med afsæt i en bestemt teknologi; Indsatstrappen. Indsatstrappen er et delelement af Sverigesmodellen.

Sverigesmodellen er en socialfaglig model, der beskrives som et mindset (Pedersen og Kloppenborg, 2017), og som omfatter en idealtænkning hvor:

- Alle børn må have en opvækst så tæt på det normale som muligt

- Tæt dialog med familien, hvorfor den enkelte sagsbehandlers sagstal skal nedbringes til omkring 20 sager

- Det tværprofessionelle samarbejde med andre professioner intensiveres med henblik på hurtig opfølgning i familien

Med et intensiveret fokus på brug af Indsatstrappen er intentionen at skabe en kontinuerlig bevægelse nedad - fra det specialiserede mod det almene - ud fra en forestilling om, at interventioner bedst lader sig udføre i almenområdet. Indsatstrappen består af fem trin; fra den mest indgribende intervention øverst på stigen, som er anbringelse på institution, og til det nederste trin på stigen som er forebyggelse. Pilen indikerer bevægelsen fra det specialiserede mod det almene. 


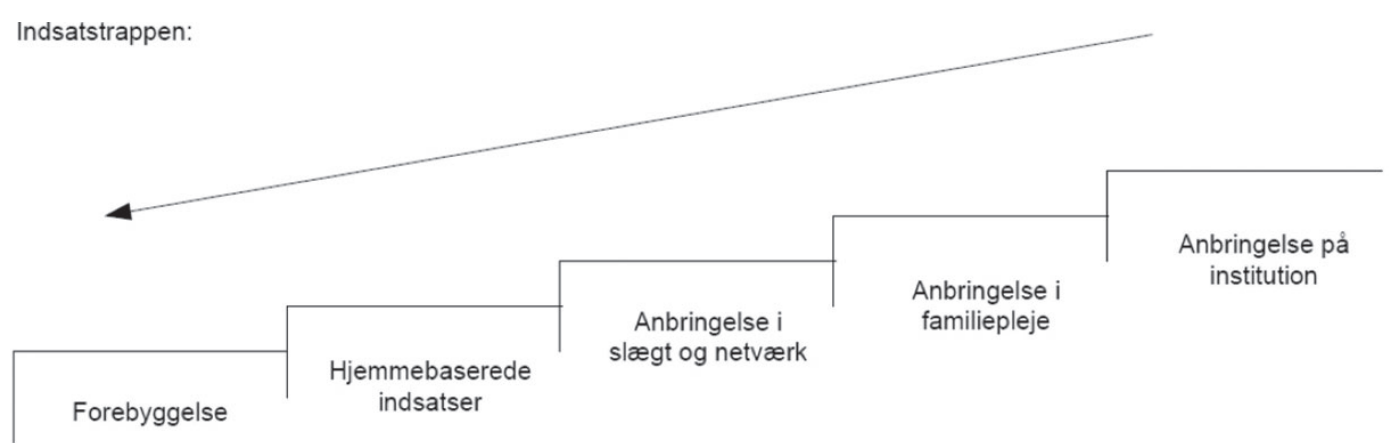

Figur 1: Indsatstrappen (Socialstyrelsen, 2018) ${ }^{1}$

Indsatstrappen er tiltænkt at være et fælles sprog og en fælles metode for faggrupperne i deres bestræbelser på at skabe ny viden i organisationen. De fire faggrupper arbejder alle i den samme organisation, men i forskellige forvaltninger: Skoleforvaltningen og Familie- og Beskæftigelsesforvaltningen.

To målgrupper står i centrum for strategien. Den første målgruppe er børn og unge, der allerede er alvorligt truede og i åbenbar risiko for varig skade. Den anden målgruppe er børn og unge i en sårbar position, der er i risiko for på et tidspunkt at udvikle særlige behov - i princippet alle børn. Strategiens målgruppeforståelse forudsætter involvering af flere professionsgrupper i relation til tidlig indsats og forebyggelse af udsathed. Det drejer sig om socialrådgivere på det specialiserede område og lærere, pædagoger og sundhedsplejersker på almenområdet. Tidlig indsats og forebyggelse skal sættes i værk igennem tværprofessionelt samarbejde.

Med udgangspunkt i nævnte udviklingsstrategi analyserer artiklen, hvordan forskellige medarbejdergrupper, via de forskellige vidensformer, eksplicit viden (teknologier) og implicit viden (fornemmelser, intuition og erfaring), operationaliserer en vision om tidlig indsats og forebyggelse af udsathed i praksis. Artiklen rejser efterfølgende en diskussion af, hvilke implikationer denne operationalisering får for det tværprofessionelle samarbejde og for muligheden for at opnå ny foelles viden i organisationen med de udsatte børn og unge i centrum.

\section{Metode}

Med henblik på at undersøge, hvordan medarbejderne operationaliserer visionen om tidlig indsats og forebyggelse af udsathed i praksis gennem forskellige vidensformer, har jeg gennemført kvalitative, individuelle interviews med fire lærere, tre pædagoger, fire socialrådgivere og fire sundhedsplejersker. Herudover har jeg gennemført gruppeinterviews - baseret på en case - med fagprofessionelle medarbejdere fra de samme informantgrupper. Gruppeinterviewene blev gennemført

1 https://socialstyrelsen.dk/tvaergaende-omrader/socialstyrelsens-viden/redskaber-til-styring-og-udvikling/indsatstrappen-1 
med henblik på at initiere diskussioner internt i faggrupperne. I alt er 72 medarbejdere interviewet.

Interviewguiden, jeg har anvendt til de individuelle interviews, bestod af brede og åbne spørgsmål og var i højere grad guidet af tema end specifikke spørgsmål. Temaerne var: 1) målgruppebeskrivelser, 2) organisering af det tværprofessionelle samarbejde, 3) handlemuligheder og valg af interventioner, 4) viden. Disse tematikker gik igen i casen, der blev anvendt i gruppeinterviewene. Tematikkerne lagde op til en refleksion blandt de fire faggrupper om, hvilke vidensformer de trækker på, når de vurderer udsathed blandt børn og unge. De fagprofessionelles refleksioner adresserede samtidig undersøgelsesspørgsmålet, der lyder: Hvorledes operationaliserer fagprofessionelle medarbejdere udviklingsstrategiens vision om tidlig indsats og forebyggelse af udsathed i praksis? Hvilke implikationer får denne operationalisering for det tværprofessionelle samarbejde og muligheden for at opnå ny fælles viden i organisationen?

Med afsæt i Polanyis $(1969,2009)$, Nonaka \& Takeuchis (1995), Wackerhausen \& Wackerhausens (1993) og Kolmos (2004) teoretiske perspektiver på implicit og eksplicit viden analyseres undersøgelsens empiriske data. De fire faggruppers perspektiver på viden har jeg således grupperet i henholdsvis eksplicitte og implicitte vidensformer. Denne operationalisering muliggør en analyse og diskussion af forskellige vidensformers betydning for det faglige arbejde med tidlig indsats og forebyggelse af udsathed i et tværprofessionelt samarbejde, hvor det tværprofessionelle samarbejde både går på tværs af professioner og sektorer i organisationen. Det tværprofessionelle samarbejde omfatter således flere typer af samarbejde og tager udgangspunkt i de fire forskellige faggruppers vurderinger af og erfaringer med tværprofessionelt samarbejde - både igennem formaliseret samarbejde, der initieres igennem mødefora og samarbejde i bredere forstand.

Det empiriske materiale præsenteres via proof- og powerquotes (Pratt, 2009) i to hovedgrupperinger - igennem medarbejdernes udtalelser om teknologier (eksplicit viden) og igennem medarbejdernes formidling af viden som mavefornemmelser, erfaringer og intuition (implicit viden). Nedenstående tabel (tabel 1) udgør artiklens proofquotes (Pratt, 2009) og viser, hvordan empirien er kategoriseret igennem en kondensering af de fire faggruppers perspektiver på implicit og eksplicit viden. Artiklens powerquotes (Pratt, 2009) er integreret i artiklens to analysedele: Medarbejdernes anvendelse af eksplicitte vidensformer og Medarbejdernes anvendelse af implicitte vidensformer i form af citater fra udvalgte medarbejdere. 


\section{Eksplicitte vidensformer}

Vi har en værktøjskasse med forskellige redskaber til løsning af problemer i forskellige typer af familier

\section{Implicitte vidensformer}

Socialrådgivere
I vores arbejde er det vigtigt med en second opinion i vores vurderinger. Det fylder meget

Jeg tænker, vi har en del tavs baggrundsviden, men vi er ikke så vant til at eksplicitere vores teoretiske perspektiver

\begin{tabular}{|c|c|c|}
\hline Lærere & $\begin{array}{l}\text { I forhold til skolefravær har vi } \\
\text { udarbejdet et redskab med } \\
\text { guidelines for handling }\end{array}$ & $\begin{array}{l}\text { Jeg tænker, vi trækker på viden, } \\
\text { vi har med i bagagen. } \\
\text { Vi er meget på mavefornemmelse } \\
\text { Hver lærer bruger sin individuelle } \\
\text { model - vi har ikke et fælles skema. } \\
\text { Jeg tænker holistisk }\end{array}$ \\
\hline Pædagoger & $\begin{array}{l}\text { Jeg bruger Børnelinealen, når jeg } \\
\text { skal lave en vurdering } \\
\text { Jeg bruger håndbogen: } \\
\text { På Tværs før jeg handler } \\
\text { Vi arbejder med et dialoghjul } \\
\text { som udgangspunkt for at diskutere } \\
\text { barnets udvikling } \\
\text { Vi bruger ABC modellen }\end{array}$ & $\begin{array}{l}\text { Jeg indsamler data omkring barnet } \\
\text { og observationer generelt, hvordan } \\
\text { er de klædt? Er de beskidte? } \\
\text { Hvordan opfører de sig? Hvordan er } \\
\text { samspillet med børn og voksne? } \\
\text { Vi bruger meget mavefornemmelser }\end{array}$ \\
\hline Sundhedsplejersker & $\begin{array}{l}\text { Vi har masser af viden om } \\
\text { tilknytningsteori og forældre-barn } \\
\text { relationen } \\
\text { Vi bruger en model, der hedder } \\
\text { Sundhedsblomsten }\end{array}$ & $\begin{array}{l}\text { Stemningen i hjemmet. Du kan } \\
\text { fornemme det, når du træder ind. } \\
\text { Du kan mærke om der foregår } \\
\text { noget her } \\
\text { I sundhedspleje arbejder vi ud fra } \\
\text { skønnet }\end{array}$ \\
\hline
\end{tabular}

\section{Teoretiske perspektiver på teknologier og implicitte og eksplicitte vidensformer}

Artiklens teoretiske perspektiver på viden trækker på teorier, der diskuterer, hvorvidt implicit viden kan gøres eksplicit. Ifølge Polanyi defineres tavs viden som en form for viden, som individet er i besiddelse af, men som ikke kan udtrykkes sprogligt (Polanyi, 1969). Polanyi argumenterer for, at den tavse viden er svær at 
sætte ord på, fordi den netop indrammer et bestemt fokuspunkt for det enkelte individs erkendelse og således er en forudsætning for, at noget fremtræder som værende meningsfuldt.

Imidlertid er Polanyis forståelse af tavs viden udfordret af organisationsteoretikere (Kolmos, 2004, Nonaka og Takeuchi, 1995, Wackerhausen \& Wackerhausen, 1993), der argumenterer for den tavse viden som noget, der kan ekspliciteres. Fokus for dem er at få det enkelte individs viden bragt i spil til brug for fællesskabet. De valgte teoretiske perspektiver præsenteres i samspil med artiklens analyser.

Teknologier i socialt og pædagogisk arbejde har ofte en dobbeltfunktion. De udgør dels et analyseredskab, som kan anvendes af den enkelte medarbejder i opsporingen af børn og unge i udsatte situationer, og dels udgør de et kommunikationsredskab i medarbejdernes koordinering af det tværprofessionelle samarbejde. Teknologierne er derfor vigtige brikker i såvel de enkelte faggruppers opsporing af udsathed som i styrkelsen af det samlede tværprofessionelle samarbejde (Laursen, 2020).

Teknologier er kendetegnet ved at være eksplicitte og optræder ofte i en skriftlig form, hvor de kan læses af den enkelte medarbejder for derefter at blive oversat til praksis (Collins 2013, Polanyi, 2009, Laursen 2020). Teknologier er ikke nødvendigvis knyttet til en bestemt type faglighed, hvorfor de ofte kan anvendes af flere faggrupper under forudsætning af, at man har eller tilegner sig de nødvendige kompetencer til at anvende teknologien. Det, der er væsentligt at understrege i den sammenhæng, er at teknologierne indeholder en drejebog, hvor den professionelle agerer ud fra en bestemt position og udfører en bestemt rolle. Herudover består en teknologi også af en redskabsdel, der guider medarbejderen i hvordan han eller hun udfører sin rolle, og endelig nødvendiggør teknologierne viden om det felt, der skal handles inden for - eksempelvis tidlig indsats og opsporing af udsathed (Laursen, 2020).

I de senere år knyttes teknologier i socialt og pædagogisk arbejde i voksende omfang til en organisation, hvor administrative ledelser ofte beslutter, hvordan specifikke teknologier bør løse specifikke opgaver. I sådanne tilfælde kan teknologien kategoriseres som en organisationsopskrift (Røvik, 1998). Organisationsopskrifter er: "en legitimert oppskrift på hvordan man bør utforme utsnitt eller elementer av en organisasjon. Det er en oppskrift som fenger og som har fått en forbilledlig status for flere organisasjoner" (Røvik, 1998). Pointen er således, at de administrative ledelser får medarbejderne til at agere ud fra en bestemt position og udføre en bestemt rolle på baggrund af en handlingsforeskrivende anvisning med et bestemt tilsigtet formål.

\section{Varians og spcendvidde i anvendelse af teknologier}

Indsatstrappen i den deltagende kommune har, i sin funktion af overlægger for den undersøgte strategi, netop karakter af at være en organisationsopskrift, idet 
den administrative ledelse i organisationen har besluttet, at den bør anvendes af alle faggrupper i kommunen- uanset organisatorisk forankring. Indsatstrappen er således hovedfokus for undersøgelsen. Imidlertid foreligger der også i offentlige organisationer ledelsesanbefalinger omkring bestemte sociale teknologier, men hvor det i sidste ende er de faglige ledere - eller måske endda medarbejderne, der afgør, i hvor vid udstrækning, de vil anvende teknologierne. Derfor vil medarbejdernes udtalelser bære præg af, at de anvender andre teknologier i arbejdet med opsporing af udsathed - enten til at kvalificere egen praksis eller som redskab i det tværprofessionelle samarbejde. Disse teknologier kategoriseres i artiklen som koncepter. Koncepter som medarbejdere i undersøgelsen refererer til som Signs of Safety (SOS), Integrated Childrens System (ICS), Børnelinealen og Circle of Security (COS). Herudover som Barnets Stemme, ABCD, Børnesamtaler og Rød, Gul, Grøn. Opsummerende kan teknologier kategoriseres som 1) organisationsopskrifter, hvoraf de kan være: 1a) ledelsesinitierede organisationsopskrifter 1b) lokalt initierede organisationsopskrifter 2) koncepter, hvis anvendelse er initieret enten af faglige ledere eller medarbejderne selv. Organisationsopskrifter er kendetegnet ved at være obligatoriske at anvende (Laursen, 2020), hvor koncepter i højere grad er kendetegnet ved at være anbefalinger.

\section{Medarbejdernes anvendelse af eksplicitte vidensformer}

I forhold til de eksplicitte vidensformer, som medarbejderne refererer til, tegner der sig et billede af, at der er en mangfoldighed af teknologier, som medarbejderne trækker ind til at afdække problemstillinger og legitimere handlinger og vurderinger. En socialrådgiver siger:

"Ja, altså ICS bruger vi meget til at afdoekke. Og herude arbejder vi også meget med Signs of Safety, og som noget nyt er vi begyndt at arbejde med COS, hvor du går ind og arbejder med familien for at hjoelpe barnet. Så bruger vi nogle andre ting som Børnesamtaler og andre voerktøjer, men jeg tæenker ICS'en som overordnet. Ja, så har vi jo hele tiden vores Indsatstrappe inde over og vurdere sagerne. Hvor er vi henne og hvor er vi på vej hen?"

Socialrådgiveren giver her et meget nuanceret billede på de teknologier, som hun bringer i anvendelse - både i forbindelse med opsporing (ICS, SOS) og med intervention (COS og Børnesamtaler). Indsatstrappen anvender hun i højere grad som en slags overbliks - eller status-teknologi.

En sundhedsplejerske udtrykker:

"Der er Børnelinealen, der er Indsatstrappen, der er -det der - rød, gul, grøn, og så har vi også en model, der hedder Signs of Safety. Det er også godt, men det er jo så en anden måde, en anden belysning på at få en familie op, og det er ikke sådan, hvor vi kategoriserer. Når vi kategoriserer inde i vores sundhedsjournal skal vi kategorisere om det er en A, B, C eller D familie." 
Igen er der en opremsning af teknologier, der anvendes til at understøtte sundhedsplejersken i hendes faglige praksis. Hun er dog ikke eksplicit med brugen af de forskellige teknologier, selvom ABCD-værktøjet bruges til at kategorisere familien. Om formålet er opsporing eller intervention er uklart. De to ovenstående eksempler viser, hvordan medarbejderne oplever at jonglere med mange teknologier i spil i bestræbelserne på at udøve den faglige opgave bedst muligt til trods for, at de teknologier, der nævnes, har forskellige funktioner.

Indsatstrappen er den strategi, der for forvaltningsledelserne står mest centralt i udviklingsstrategien. Rettes opmærksomheden mod indsatstrappen tegner der sig et billede af, at de fire faggrupper ikke tilskriver den samme betydning, jf. tabel 2 .

\section{Faggruppe Indsatstrappen}

Socialrådgivere $\quad$ Vi vil jo også gerne ned ad indsatstrappen igen, men nogle gange kan problematikkerne være så store, at det ikke giver mening at snakke om at komme ned ad trappen, men det skal helst ikke gå opad

Der er ingen tvivl om, at det nye er, at vi skal ned - vi skal ned ad trappen

I forhold til inddragelse af indsatstrappen med andre samarbejdspartnere: Jeg oplever ikke, at vi er så gode til at få det sagt, men jeg tænker at dem omkring os også ved, vi arbejder ud fra den

\begin{tabular}{ll}
\hline Lærere & Vi er slet ikke ude på trappen med de børn, vi har \\
& Vi bruger ikke trappen direkte, men den grundlæggende forståelse af den \\
& - vi prøver at løse problemet på lavest mulige niveau \\
& Har ikke hørt om Indsatstrappen... og det er der ikke ret mange her, der \\
har & Vi ligger nede i bunden af den, så vi kigger egentlig ikke på den... Det ville \\
& jo mest være et redskab vi skulle bruge, hvis vi skulle se på, hvordan vi \\
& skulle have barnet ned ad trappen og der ligger vi jo allerede \\
Pædagoger & Jeg har hørt om indsatstrappen, men jeg bruger den ikke i hverdagen \\
& $\begin{array}{l}\text { Den er ikke med i faglige refleksioner... og så alligevel man prøver jo altid } \\
\text { at forebygge først. }\end{array}$ \\
\hline Vi bruger ikke trappen direkte, men den grundlæggende forståelse af den \\
- vi prøver at løse problemet på lavest mulige niveau \\
Den giver ikke så meget mening for os
\end{tabular}

Tabel 2: Theilmann, 2020 
Imidlertid er det interessant fra både et organisatorisk og fagprofessionelt perspektiv, at hverken socialrådgiveren eller sundhedsplejersken nævner teknologierne i relation til det tværprofessionelle samarbejde. Her kunne de fagprofessionelle have fremhævet Indsatstrappen i kraft af dens centrale rolle i udviklingsstrategien og dens tiltænkte funktion i det tværprofessionelle samarbejde. At dette ikke er tilfældet indikerer, at Indsatstrappen ikke tilskrives anvendelighed eller meningsfuldhed af de pågældende faggrupper i løsningen af den faglige og tværprofessionelle opgave, eller at Indsatstrappen (og de øvrige teknologier) ikke er blevet implementeret i en daglig tværprofessionel praksis.

At teknologier er udarbejdet med et bestemt formål (de kan fungere som drejebog med en tilhørende manual) gør, at de kan indgå som et redskab til løsning af en specifik problemstilling. At de samtidig også anvendes som universal-teknologi, som det er tilfældet, når eksempelvis Indsatstrappen skal fungere som en overlægger for strategien, så fører det til, at teknologien for det første anvendes på andre problemstillinger end den er udviklet til at kunne løse, for det andet at den opleves at komme til at stå i et modsætningsforhold til anden eksisterende viden, særligt den mere implicitte vidensform, der kommer til udtryk som praksisbaseret erfaring. En socialrådgiver fortæller:

\begin{abstract}
"Det kan voere, man kommer til at bruge Indsatstrappen til at sige: ‘jamen nu er det jo så fordi vi arbejder med Indsatstrappen, og det er det rigtige at gøre og det er supersmart'. Hvor rådgiverne kan sidde og voere uenige med fx at jeg synes faktisk, vi bør anbringe den her pige. Man kan sige, at aflastning er nok, men så kan det gemme sig lidt under, at nu arbejder vi efter Indsatstrappen...at den kan overtrumfe rådgivernes faglige vurdering... "
\end{abstract}

og en anden socialrådgiver fortsætter:

"vi skal jo også nedad, men der toenker jeg, at ja, vi skal nedad, når det giver mening.
Det er ikke for alt i verden, at vi skal gå ned, men giver det mening, så giver det mening.
Nogle gange kommer vi bare ikke uden om, at vi skal opad, fordi det skaber den trivsel,
der skal til, at de også kan integrere sig den anden vej også. Så jeg er lidt ambivalent
med den, fordi jeg egentlig også godt kan toenke den som en økonomisk reference, når vi
siger, at vi skal nedad. Det skal vi, men ikke endnu... og så må vi tage den kamp, ikke?"

De to udtalelser fra socialrådgivere retter opmærksomhed på, at Indsatstrappens drejebog, der fokuserer på mindst mulig indgriben i barnets liv og et liv så tæt på det normale som muligt, kan være i konflikt med god socialfaglig praksis om det gode liv for barnet. Herudover foreskriver Indsatstrappens drejebog også en nedadgående bevægelse $\mathrm{i}$ indsatserne $\mathrm{i}$ retning fra det specialiserede til det almene, hvilket i en socialfaglig optik ikke nødvendigvis anerkendes som den rigtige indsats. Den samme refleksion gør sig gældende hos en lærer:

"Det der med en tidlig indsats, at vi skal ned ad den trappe...vi skal helst hele vejen ned. Men jeg tror alligevel nogle laerere og paedagoger vil sige: Jamen, hvorfor sker der ikke 
noget? ... og det må da voere et udtryk for, at man synes, man skal op ad trappen, og det kan også nogle gange vore nødvendigt."

Medarbejderne giver udtryk for, at de betragter Indsatstrappen som en teknologi, der i den rette kontekst kan give mening at anvende, men at de absolut ser dem i sammenhæng med anden viden, som for dem har større gyldighed (deres professionsfaglige eller erfaringsbaserede viden).

Der er også eksempler på, at medarbejderne oplever teknologierne som direkte kontraproduktive i forhold til den faglige opgave. En socialrådgiver siger om ICS konceptet:

"Det er jo et redskab, der er givet... (ICS). Det er en måde, vi kan organisere viden på, og så kan vi selvfølgelig gøre det synligt for skolerne også. Men de bliver bare så omfangsrige og fragmenterede, så indtil videre har jeg mest oplevet det som et irritationsmoment"

Og en anden socialrådgiver fortsætter:

"Så griber man noget $i$ Sverige (Indsatstrappen), uh, så bliver det, det nye hurra-ord. $V i$ skal arbejde efter den her model, men så laver man sin egen kommunale model, som alligevel ikke er sådan. Jeg synes, der mangler sammenhoeng og retning."

Dette understøttes af en anden lærer:

"For der er jo den med, at mange toenker, at nu goelder det bare om at fä alle ned $i$ almenområdet... og så skal vi lave noget mere... Man går helst ikke op ad den der trappe, man går helst ned, og alle dem vi kender, der burde man gå op."

Som det fremgår af ovenstående, så indeholder det empiriske materiale talrige eksempler på teknologier, som medarbejderne refererer til i deres bestræbelser på at arbejde målrettet med tidlig indsats og forebyggelse. Generelt er der stor spændvidde i medarbejdernes tilgang til og anvendelse af eksplicitte vidensformer - fra medarbejdere, der henviser til teknologier uden nødvendigvis at forholde sig til, hvordan de virker i deres pågældende praksis - og til en reflekteret henvisning til teknologier som en del af det vidensgrundlag, medarbejderne udarbejder deres faglige praksis på baggrund af, herunder også en kritisk stillingtagen til teknologiens bidrag til løsning af den faglige opgave.

Medarbejdernes forskellige perspektiver på tilgangen til og anvendelsen af teknologierne afspejler, at nogle teknologier netop er obligatoriske, hvor andre teknologier er et frivilligt valg. Den kritik, som medarbejderne retter mod teknologierne er forskelligartet - såvel i indhold som i retning. I forhold til Indsatstrappen ser socialrådgiveren den som en forsimplet udgave af Sverigesmodellen, og kritikken rettes derfor mod den kommunale oversættelse af den (reduktionen til Indsatstrappen), hvor læreren ser den som fejlvalg i relation til løsning af den faglige opgave. Indsatstrappen er en interventionsmodel, der har fokus på at minimere sociale indsatser for at sikre et barn et liv så tæt på det normale som muligt. 


\section{Medarbejdernes anvendelse af implicitte vidensformer}

Medarbejderne trækker i høj grad på implicitte vidensformer, der kommer til udtryk via beskrivelser som fornemmelser, erfaringer og intuition, altså tavse vidensformer. En socialrådgiver udtrykker det således:

\footnotetext{
"Og det er der, hvor jeg godt ved, at mavefornemmelse, det kommer vi ikke altid så langt med, men jeg toenker, at nogle gange er der bare er en mavefornemmelse, og sådan er det jo også, når vi laver vores analyser $i$ vores børnefaglige undersøgelser - der er faktuelle ting, vi kan analysere og så er der nogle ting, man bare kan morke."
}

Interviewuddraget med socialrådgiveren kan fortolkes ud fra Nonaka og Takeuchis (1995) vidensdimension, hvor den viden, der er i spil, er og forbliver tavs og er afhængig af fysisk tilstedeværelse såvel som af tid og sted. Viden aktiveres og produceres her ud fra en praktisk hands-on tilgang, men er samtidig subsidiær (Polanyi, 2009), idet erkendelsen af en given problematik bliver beskrevet som en mavefornemmelse, noget der kan mærkes, men ikke italesættes. En anden socialrådgiver siger: "Vi er meget på mavefornemmelse. Mavefornemmelsen er selvfølgelig forankret i nogle faste tankemønstre." Igen bliver der her refereret til mavefornemmelsen som noget subsidiært, der fungerer som det grundlæggende tavse, og som er en forudsætning for den synlige viden (Polanyi, 2009). Der refereres således til nogle faste tankemønstre, der både kan fortolkes som grundlæggende faglig teoretisk viden og som teknologier.

Socialrådgiverne forsøger igennem ovenstående citater at indfange den viden, der er så svær at forklare, konkretisere og eksplicitere, nemlig viden, som er situeret, kropslig, sanselig eller konkret (Polanyi, 2009). Også hos sundhedsplejerskerne kommer dette vidensperspektiv til udtryk: "Vi snakker tit om det faglige skøn. Det er sådan lidt uhåndgribeligt, men det er en samlet fornemmelse, man får, når man har været sammen med familien i en halv time eller tre kvarter." En anden sundhedsplejerske konstaterer kort og godt: "Den der intuition er set igennem nogle faglige briller”. Også blandt lærerne og pædagogerne i undersøgelsen træder implicitte vidensformer frem: "Jeg tænker, at vi benytter den viden, vi selv har med i bagagen. Det handler i virkeligheden mere om, hvem vi er som personer." Citatet stammer fra en lærer, men repræsenterer i virkeligheden også, hvad mange pædagoger udtrykker og sætter fokus på, nemlig at viden er meget mere end hvad der ekspliciteres - og ikke mindst, at viden altid skal forstås som indlejret kulturelt og principielt (Kolmos, 2004). Samlet set går det igen blandt de fire forskellige professionsgrupper, at implicit viden ikke blot er at betragte som personlige synsninger. Den er også forankret fagligt og erfaringsmæssigt.

Styrken for den implicitte viden, som den kommer til udtryk blandt de professionsfaglige medarbejdere, er at den løser en lang række af daglige og faglige udfordringer i den monofaglige jobfunktion. Medarbejderne genkender problemstillinger, som de har mødt før, og de handler intuitivt på baggrund af erfaringer, de har erhvervet sig. Herved afpareres mange problematikker i almenområdet før 
de udvikler sig til henholdsvis PPR-sager eller myndighedssager - eller det medarbejderne beskriver som at gå op ad trappen - netop fordi den implicitte viden, i kraft af dens kulturelle og principielle indlejrethed, bliver en rutiniseret handling (Laursen, 2020). Problemet for den implicitte viden er netop dens mangel på eksplicitering, hvilket gør den svær at anerkende - særligt i en tværprofessionel sammenhæng, hvor særligt fælles sprog italesættes som forudsætning og som en målsætning i sig selv. Implicit heri ligger en betragtning om, at analyser og skøn normalt udmøntes i beslutninger, som skal kunne begrundes eksplicit også over for andre samarbejdspartnere, som eksempelvis forældre.

\section{Implikationer for udmøntning af tidlig indsats og forebyggelse i tvcerprofessionel praksis}

At teknologier - og særligt Indsatstrappen - har en fremtrædende plads i offentlige forvaltninger er relativt nemt at forstå; teknologier har til formål at skabe løsninger på specifikke problemstillinger. De er eksplicitte i deres udtryk og er derved ideelle at skabe "fælleshed"med; fælles sprog, fælles forståelse og fælles handling. Teknologier er procedurelle og deklarative, og de er driftsikre på den måde, at de i høj grad løser den problematik, de er sat i verden for at løse (Røvik, 1998). De indfanger en regelmæssighed, men sker der afvigelser i forhold til et eller flere af teknologiens tre elementer (viden om feltet, manual eller drejebog), så opstår der problemer. Udfordringen bliver særligt tydelig, når teknologierne forventes at kunne løse problemer, der ligger ud over det, de er sat i verden for at løse. Som det er fremgået i foregående afsnit, så forekommer dette eksempelvis når der sker en sammenblanding af, hvorvidt der er tale om en opsporings- eller en interventionsteknologi, eller hvis de tre delelementer (viden, manual, drejebog) ikke bringes i anvendelse. Her har teknologierne en begrænsning, medmindre de falder i hænderne på en medarbejder, der er i stand til at kombinere teknologierne med egen erfaring og professionsfaglighed. Medarbejderne giver - som det fremgår af det empiriske materiale - mange eksempler på anvendelse af implicitte vidensformer som mavefornemmelse, intuition, erfaring og skøn og forklarer, hvordan de derfor forsøger at kompensere for forhold, som teknologien ikke kan adressere. Den implicitte viden bidrager således til at kvalificere den enkelte medarbejders håndtering af daglige faglige udfordringer. Imidlertid fremstår den tavse viden som noget svag, når der skal samarbejdes med andre professioner, der ikke har den samme indlejrede kulturelle viden.

Tværprofessionelt samarbejde kan derfor komme til at handle om dem, man samarbejder med (og de fortællinger, der knytter sig til de forskellige faggrupper) i stedet for den fælles opgave, der skal samarbejdes om (tidlig indsats og forebyggelse). Netop i dette spændingsfelt imellem eksplicit og implicit viden opstår spørgsmålet om, hvordan ny viden i organisationen skabes og faciliteres. På den ene side fremstår teknologier, qua deres ekspliciterbarhed og handlingsforeskrivende form derfor som et udmærket udgangspunkt for at skabe forandringer i 
organisationen, men de må samtidig forstås ud fra deres begrænsning; at de kun kan være løsning på de problematikker, de er sat i verden for at løse. Teknologiernes eksplicitte karakter kan derfor være et godt udgangspunkt for at skabe fælles viden i organisationen. På den anden side er der mange andre former for viden i spil i organisationen, der også potentielt kan tilføre nyt til organisationen, nemlig mere implicitte vidensformer. Eksempelvis den form for viden, som Nonaka og Takeuchis (1995) betegner tavs til tavs viden. Tavs til tavs viden handler om at skabe vidensdeling gennem fælles erfaringer, der er afhængig af fysisk tilstedeværelse igennem en praktisk hands-on tilgang. Ved at være sammen og dele udfordringer, opgaver og erfaringer, kan organisationen udnytte den eksisterende tavse viden - også tværprofessionelt. Et andet forhold handler om at sikre, at viden, der kan italesættes, men som ikke bliver det, kan ekspliciteres. Dette kan belyses ud fra Wackerhausen og Wackerhausens (1993) definition af aktuel tavs viden, eller ud fra Kolmos' (2004) begreb om aktuel indlejret viden. En lærer udtrykker det således: "det handler også om kommunikation. Ofte er det et spørgsmål om hvad vi IKKE får at vide." Eller som en socialrådgiver siger: "Tja, man kan sige at vi er lederne her. Vi kender alle informationer, men vi behøver ikke nødvendigvis at dele dem." Når viden ikke bliver delt, kommer den tavse viden i høj grad til at blive hos/i den enkelte medarbejder, og den bliver således ikke et aktiv for organisationen. Af samme grund er den tavse viden svær at anvende i en tværprofessionel sammenhæng, hvor medarbejdere skal sikre organisationen ny fælles viden.

\section{Konklusion}

Udviklingsstrategiens fire professionsgrupper (socialrådgivere, lærere, pædagoger og sundhedsplejersker) anvender et konglomerat af vidensformer - fra eksplicitte teknologier til implicitte vidensformer - i det faglige arbejde med tidlig indsats og forebyggelse af udsathed. Teknologierne udgøres af organisationsopskrifter og koncepter, som enten er ledelsesinitierede, som det er tilfældet med Indsatstrappen, eller fagligt initierede af faglige ledere eller professionsgrupper. De implicitte vidensformer kommer til udtryk igennem medarbejdernes mavefornemmelser, intuitioner og erfaringer i bestræbelserne på at operationalisere strategiens vision om tidlig indsats og forebyggelse af udsathed til en meningsfuld og håndgribelig praksis.

Den obligatoriske teknologi, Indsatstrappen, er tiltænkt at være en samarbejds- eller kommunikationsteknologi, der kan tilføre ny viden til organisationen i kraft af, at den kan agere fælles sprog, fælles forståelse og fælles metode. Særligt $\mathrm{i}$ almenområdet opleves problemer med at anvende og udmønte Indsatstrappen meningsfuldt i praksis. Den adresserer ikke almenområdets udfordringer i relation til tidlig indsats og forebyggelse af udsathed og kan derfor ikke være det fælles sprog, eller den fælles forståelse mellem medarbejdergrupperne, som den er tiltænkt i det tværprofessionelle samarbejde. 
Internt mellem de fire medarbejdergrupper leder organisationens valg af teknologier, og i særdeleshed Indsatstrappen, til implikationer for samarbejdet, idet valget af Indsatstrappen implicit understøtter socialfaglige perspektiver på tidlig indsats og forebyggelse af udsathed. Dette afspejles også i det tværprofessionelle samarbejde, hvor medarbejderne selv italesætter denne implikation for samarbejdet. Det er ikke tydeligt for medarbejderne, hvad de enkelte teknologier, og i særdeleshed Indsatstrappen, kan bidrage til løsning af, samt hvornår teknologierne bør tages i anvendelse. Denne mangel på gennemsigtighed og mening fører til, at medarbejderne tager teknologier i brug, der ligger tættere på egen professionsbaggrund - eller trækker på helt andre vidensformer - som eksempelvis implicit viden, der muligvis kan kvalificere egen praksis, men som tydeligvis ikke er velegnet i en tværprofessionel praksis qua dens implicitte karakter.

\section{Litteratur}

Bourdieu, P., \& Passeron, J.-C. (2006). Reproduktionen: bidrag til en teori om undervisningssystemet. Hans Reitzel

Collins, H. (2013). Tacit and Explicit Knowledge, Univercity of Chicago Press

Kolmos, A. et al (2004). Viden er tavs, men 'larmende' $i$ sit udtryk. Research Report 2, Department of Development and Planning, AAU

Laursen, E. (2020). Sociale teknologier og samarbejde om udsatte børn og unge. Aalborg Universitetsforlag (in press)

Nonaka, I. and Takeuchi, H. (1995). The Knowledge Creating Company: How Japanese Companies Create the Dynamics of Innovation. Oxford University Press

Ringø, P. et al. Menneskesyn i socialt arbejde. (2018). Akademisk Forlag

Pedersen, H. S. og Kloppenborg, H. S. (2017). Slutevaluering af Herning Kommunes Sverigesprogram. Kora

Polanyi, M. (1969). Knowing and Being. University of Chicago Press

Polanyi, M. (2009). The tacit dimension. The University of Chicago Press

Pratt, M. G. (2008). Fitting Oval Pegs Into Round Holes. Organizational Research Methods, 11(3), 481-509. DOI: 10.1177/1094428107303349

Røvik, K. A. (1998). Moderne organisasjoner: trender i organisasjonstenkningen ved tusenårsskiftet. Fagbokforlaget

Røvik, K. A. (2007). Trender og translasjoner : ideer som former det 21. århundrets organisasjon. Universitetsforlaget

Schein, E. H. (1994). Organisationskultur og ledelse. Valmuen

Theilmann, B. (2018). Sverigesmodellens organisatoriske rejse fra Sverige til DK. En udfordring for frontmedarbejere. Social Kritik, 156: 53-67

Theilmann, B. (2020). Interdisciplinary cooperation in the field of measure, means and methods: A challenge to welfare professionals. Nordic Social Work Research. DOI.org/10.1080.21568 57X.2020.1724188

Udviklingsstrategi for børn, unge og familier i Aalborg Kommune 0-18/23 år. (2016)

Wackerhausen, B. \& Wackerhausen, S (1993). Tavs viden og podagogik, Dansk Pædagogisk Tidsskrift, 4: 190-201 